\title{
Who is (Still) Socializing with Neighbors? A Contribution to the Analysis of Local Social Relations $^{1}$
}

\author{
Geran-Marko Miletić \\ Institute of Social Sciences Ivo Pilar, Zagreb, Croatia \\ e-mail: Geran.Marko.Miletic@pilar.hr
}

\begin{abstract}
Disembedding of social relations from a local context has often been pointed out as one of the main characteristics of contemporary social changes. Taking that as a starting point, this paper explored the role of neighborhood social relations in contemporary Croatian society. The analysis presented in this paper had two aims. The first aim was to get insight into structure of local social relations in Croatia and the second one was to determine whether dynamics of local social relations are related to some demographic, socioeconomic or spatial characteristics. Data analyzed in this paper were collected through the survey entitled Pilar's Barometer of Croatian Society. The survey was conducted in the spring of 2014 on the national representative sample of Croatian citizens aged 18 years and older $(N=1000)$. Findings from the analysis indicate that neighboring is a usual form of social interaction for majority of the target population. Furthermore, analysis showed that the level of education and the size both of settlements and buildings where respondents live are the most important determinants of neighborhood social relations. In addition, the analysis revealed that years of residence at the present address are particularly important for density of neighborhood social relations.
\end{abstract}

Key words: local social relations, neighborhood, local community, social cohesion, Pilar's Barometer, Croatia.

$\mathbf{1}$ This work has been fully supported by the Croatian Science Foundation under the project number 1875 Second Homes and Social Sustainability of Local Communities in Croatia. Any opinions, findings, and conclusions or recommendations expressed in this material are those of the author and do not necessarily reflect the views of the Croatian Science Foundation. 


\section{Introduction}

During the 20th century, modernization pressure prompted by economic and technological development - first within the framework of the process of industrialization and subsequently within the framework of post-industrial transformation - has changed not only the social structure but also a way of life of the Western civilization. The processes of forming new social actors as well as changes in the nature of relationships within existing social institutions that were started then, have continued into the early $21^{\text {st }}$ century, but now dominantly influenced by the expansion of information and communication technology. This circumstance, in addition to further increasing dynamics of the mentioned processes, contributes to a significant increase in the number of the individuals that are capable to form social identity independently of territorial and/or kinship-based influence.

However, settlements and residential clustering are still a prevailing type of human dwelling regardless of the expansion of the space of flows (Castells, 2000), improvements in transportation infrastructure and increased population mobility in general, including the changed direction of mobility seen in some forms of multi-territorial practices showing signs of counter-urbanization tendencies (Halfacree, 2012). Spatial and temporal proximity leads to repeated accidental encounters between people who dwell near each other which generally become a good introduction into social interaction that often results in creating more or less stable and strong social relations.

Consequently, a settlement is not only a space occupied by houses and apartments but also a space filled with more or less dense agglomerations of social relations. The totality of these elements creates a specific social ambience and eventually transforms a space into a place, or a settlement. Naturally, in addition to other influencing components, character of local social ambience crucially dependens on the structure of local social relations that varies from settlement to settlement, from culture to culture, from one era to another.

Starting from there, this paper focuses specifically on the local social relations in Croatian society. By exploring the structure of social interactions among a group of people living near one another, an attempt was made to answer the question whether local social relations still matter, and to whom.

\section{Relevance of Neighborhood for the Analysis of Local Social Relations}

In this paper, local social relations were analyzed at the neighborhood level. Neighborhood is the space that we first enter whenever we leave our home. Thus, this is the space where our privacy is no longer protected but it is still known to us and in a way predictable, and therefore it remains (or becomes) a space of familiarity and closeness.

Neighborhood seen in this way holds an important place in the theories of dwelling in which the identity aspect is given a role that is at least as important as the 
technical dimension of satisfying primary and secondary physiological needs. An understanding of dwelling taking such broader view starts from an unquestionable human aspiration for belonging and action. This aspect is particularly emphasized in the work of Norberg-Schulz (1990) who brings dwelling into a context of shaping a personal way of existence that is inseparable from the space where it is being realized, differentiating there three levels of dwelling: collective, public and private. Similarly, Kemeny (1992) deems that the relationship between a household and a dwelling it occupies cannot be separated from their local settings, from a settlement form and social structure within which the habitation takes place. Neighborhood is also specifically referred to in the work of Chombart de Lauwe (1961), a co-founder of the sociology of housing who, when conceptualizing dwelling, introduced also a problem of optimal neighborhood as one of the essential topics.

In this paper, relying specifically on the concept of dwelling that emphasizes the importance of local settings in our everyday existence, neighborhood is approached not only as a spatial entity but also as a specific form of territorialized social relations that influence both the position of an individual in the larger society and his everyday actions.

For the neighborhood-focused analysis it is important to emphasize that there is no consensus in scientific literature about the definition of neighborhood, not only at the operational but also at the conceptual level. From one perspective, neighborhood, though hard to define, is what everyone knows when they see it (Galster, 2001) and from the other, neighborhood is not recognised but constructed based on certain expectations and idealized images of what a neighborhood should look like (Martin, 2003).

Within these differences, it is possible to distinguish two main approaches to conceptualizing and defining the term 'neighborhood'. The first tends to territorially encompass some form of community, that is, the term neighborhood denotes a specific geographic area where networks of friendships overlap (Hipp, Faris and Boessen, 2012). In this approach which integrates social and ecological perspective, neighborhood is seen in the spaces where these networks are denser. In other words, the overall density of social ties suggests formation of intensely interconnected groups which then opens the door for establishing local communities - in the sense that relationships within a group of people sharing a given locality imply more than accidental acquaintances. Such a "group shares some common goals, values, and, perhaps a way of life that reinforce each other, creates positive feelings, and results in a degree of mutual commitment and responsibility" (Bruhn, 2011:11). The basic characteristic of this approach is that it defines neighborhood as non-overlapping entities determined by the physiognomy of space and directions of communication lines.

Criticism given to such an understanding of neighborhood can be taken as a warning that by equalization of neighborhood with (local) community, multistrandedness and boundary-crossing of social connections step out of focus (Wellman and Leighton, 1979). For Wellman and Leighton, neighborhood is, first of all, the place that accepts various types of social relations, and one of them may also be a (local) 
community. However, there could be, and are, neighborhoods with weak social relations and consequently with a lack of community spirit.

The content of this previous criticism represents a basis for definition of another approach to neighborhood. It does not give up an attempt to delineate boundaries of neighborhood. However, it starts from the assumption that neighborhood is a multilayered socio-spatial phenomenon which means that it includes several levels of boundaries. This multilayeredness does not result from overlapping of social relations only, it is also caused by complexity of the role that neighborhood has in a wider social system. Thus, Hunter (1979, according to Martin, 2003:364) emphasizes that neighborhood is a socio-spatial organization that is positioned "between forces and institutions of the larger society and the localized routines of individuals in their everday life". Both Forrest and Kearns (2001) draw attention to the function of a broader living space changing over time, which is also important when defining neighborhood. According to these authors, whereas neighborhood formerly had an important role to compensate for some basic functional limitations of apartment, today it is mostly a space for recreation and leisure and also important part of one's identity. In other words, this approach starts from the fact that problem of defining neighborhood is not only a matter of geography and of finding a clear boundary between two neighborhoods but also of determining what should be found within these boundaries. This lead was followed also by Suttles (1972, according to Forrest and Kearns, 2001) in his definition of neighborhood through four hierarchical levels: face-block, defended neighborhood, community of limited liability and the expanded community of limited liability. Modifying this hierarchical concept, Kearns and Parkinson (2001) analyzed neighborhood through three levels: home area, locality and urban district or region.

For the purpose of this analysis, both of these two concepts were used as a starting point for defining neighborhood. More precisely, the lower neighborhood levels in these hierarchies were taken as a frame of reference. The lowest neighborhood level in Suttles's hierarchy is the individual one, different for each individual, with no strong boundaries and in practice reduced to a space within which children are allowed to play without supervision (Galster, 2001). The lowest level as defined by Kearns and Parkins (2001), refer to an area important for psycho-social benefit of the individual by establishing closeness and togetherness. Dimensions of the area indicated by both concepts are determined based on human measure, and in researches the borders of this area are most often defined as a 15-minute walking distance from one's home (Jelić and Löw Stanić, 2014; Kearns and Parkinson 2001; Svirčić Gotovac, 2006). This particular lowest neighborhood level is a topic of interest addressed in this paper, and the indicated time-radius was used for delineating the boundaries of space within which were examined local social relations in this research.

\section{Local Social Relations and Social Cohesion in Neighborhood}

Dealing with local social relations is very often motivated by search for those particular forces that keep together individuals living near one another. Such approach, focused on the problem of cohesion could be found even in sociologist classics such 
as Durkheim, Simmel or Park, who in their work problematise influence of rapid urbanization on social disorganization. Topics like local social ties, social anomie and social control were often in focus of their interests (Kubrin and Weitzer, 2003). The approach that highlights importance of local social relations in looking for solution to the problem of poverty, inequality, social fragmentation and social exclusion has not lost its relevance even nowadays. One of the attempts to remediate consequences of mentioned contemporary social problems is aimed at encouraging establishment of socially sustainable communities, where strengthening of social cohesion in neighborhood plays an important role (Colantonio and Dixon, 2010; Dempsey, Bramley, Power and Brown, 2011).

As is already known for the relations at the group level, character and dynamics of interaction among members influence group vitality. Higher group vitality strengthens capacity for integration, and consequently the overall power for collective action. Transposed to relations at the level of neighborhood, a group's vitality along with higher degree of interaction and denser relationships within neighborhood enable more successful use of available resources, and consequently, a group of people living close to each other becomes stronger for easier coping with problems they encounter as a collective. Stronger social cohesion within neighborhood leads toward building community spirit that serves as a source for collective action (Forrest and Kearns, 2001).

All so far presented suggests that the concept of social cohesion has many layers and dimensions. In its core it is determined by the social relations, that is, by the dynamics of social interaction. However, it is also determined by less tangible elements, in the first place by the way one perceives social ambience where social relations are realized. The list of dimensions on which different authors base their own conceptualizations of social cohesion does not end here. For instance, when analysing social cohesion in the context of neighborhood, Buckner (1988) was focused on residents' sense of community, degree of attraction to live in neighborhood and degree of interaction within neighborhood. Smith in his analysis (1975, according to Kramer, Seedat, Lazarus and Suffla, 2011) takes somewhat broader view of social cohesion, linking it with the use of physical facilities, personal identification, social interaction and value consensus. Forrest and Kearns (2011) define five basic dimensions of social cohesion: (1) common values and a civic culture, (2) social order and social control, (3) social solidarity and reductions in wealth disparities, (4) social networks and social capital and (5) place attachment and identity.

Common denominator of all these concepts is the notion of neighborhood social cohesion as a synthetic indicator of social integration of this specific place-based community. In this sense, it is clear that there is no social cohesion without social interaction, and therefore social cohesion speaks of the character of social relations that are being established based on social interaction. Additionally, from the definitions provided, it is evident that the concept of social cohesion includes one additional dimension. Along with objective elements in the form of social interactions with neighbors, subjective perception of local social relations has also a major role for the establishment of social cohesion. This latter dimension is close to the concept 
of the sense of community (Buckner, 1988), and it involves a psychological concept that is focused on a problem of experience relating to space where one lives. The sense of community reflects "people's perceptions of their locality, their feelings toward it, their sense of belonging, and their relationships within it" (Filipovič Hrast and Dolničar, 2012:319).

Taking into consideration these two main dimensions of local social relations, the focus of the analysis in this paper has narrowed solely to the objective dimension of social relations with neighbors, while the elements that constitute perceived (subjective) experience of local social relations were not in the scope of this paper.

\section{Determinants of Social Relations in Neighborhood}

In pursuit of the determinants of neighborhood social relations, a longitudinal study of local social relations in the United States (Guest and Wierzbicki, 1999) imposes itself as an important reference point. Using data collected in the General Social Survey from 1974 to 1996 , the study analyzed trends in socializing with someone from neighborhood and with friends living outside the neighborhood. Findings obtained in the study over the analyzed period showed a decline in frequency of socializing within neighborhood concurrent with an increase in the frequency of socializing with people living outside the neighborhood boundaries. This change in frequency of local and extralocal social relations has two additional characteristics. The first is that, in the observed period, the bottom line of socializing indicates net loss - the decline in frequency of socializing within neighborhoods was greater than increase in frequency of socializing with friends outside the neighborhood. The second is that despite the decline in socializing within neighborhoods, this type of social interaction is still important for a sizable segment of population; whereas in the first analyzed year $61 \%$ of respondents reported spending a social evening with neighbors once a month or more, in the last analyzed year that number decreased to about $52 \%$. Furthermore, the mentioned decline in the frequency of socializing within neighborhood is not characteristic for all social groups. The analysis showed that among older people and among people outside labour market, frequency of local social relations has not changed significantly. Concerning the determinants of the frequency of socializing with neighbors, the analysis showed that in the American society younger people and those without children tended to socialize with neighbors more often, whereas education and work status of respondents were only slightly associated with frequency of social activities with neighbors.

Another interesting analysis of local social relations in the American context, conducted by Katherine King (2013) started from the hypothesis developed by Jane Jacons (1961) that healthy social relations in a city result from a spontaneous organic process rather than from grand planning schemes. Based on empirical research conducted in Chicago, the analysis offered insights that speak in favor of the connection between the types of neighborhood development and the character of local social relations. King concludes that local social relations are more successfully maintaned and even more easily established in the neighborhoods where development occurs 
gradually and represent a kind of evolutionary process than in the neighborhoods created as a result of more extensive and large-scale planning.

Insights gained through researches carried out geographically closer to Croatia, as is the study of sense of community conducted across the six neighborhoods in three different settlements in Italy, indicate that in the European neighborhood patterns of establishing local social relations depend, to some degree, on particular demographic and socioeconomic characteristics of actors involved (Prezza, Amici, Roberti and Tedeschi, 2001). Main findings from the study suggest that intensity of social relations considerably varies from neighborhood to neighborhood, and a detailed analysis showed that elements such as sex, age, education, years of residence at current residential address, number of household members, number of children, family status and involvement in local activities are relevant for the structure of local social relations.

Filipovič Hrast and Dolničar (2012) analyzed the same topic (sense of community) in their research conducted in two neighborhoods in Slovenia: one was the zone of collective and the other of individual type of housing. The analysis showed substantial differences between the two neighborhoods in the level of local social interactions. In the settlement characterized by high-rise buildings, heterogeneity of population, frequent social problems and well-developed commercial activities, the values obtained on the instrument measuring level of social contact in the neighborhood were lower than in the settlement with predominantly middle-class population, homogeneous social structure, prevailing individual family houses, fewer social problems and less commercial activities. Relationship between individual characteristics of respondents and degree of social interaction with neighbors differred between the two analyzed neighborhoods. In the settlement with lower level of local social interaction as a more significant determinant of relations with neighbors were number of years spent at the residential address and attitude about importance of friendship, whereas in the other neighborhood, characterized by a higher degree of local social interactions, the list of determinants was somewhat longer and in addition to two mentioned determinants, includes apartment ownership and attitude on the importance of work and family. Based on these findings, the authors conclude that contextual differences, that is, characteristics of the neighborhood itself, have a kind of catalytic role in forming local social relations.

Problematising social relations in the context of neighborhood has certain tradition in Croatia as well, and this topic was very often included in sociological studies that were conducted for the purpose of urban planning, particularly during 70-ies and 80-ies of the 20th century (Seferagić, 1988). Such special-purpose sociological studies encompassed different dimensions of social interaction in neighborhood including the perception of local social relations. However, since these studies had primarily practical purpose, conducted analyses were generally of descriptive nature and did not explore determinants of social relations in neighborhood more deeply. More recent researches conducted in Croatia used social relations mostly as an explanatory variable, primarily in the context of quality of living in neighborhood and attachment to neighborhood. For instance, when exploring the quality of living in Rijeka, as an indicator was used overall satisfaction with neighborhood, and conducted analysis showed greater satisfaction in persons who are owners of the apart- 
ment they live in, those who have positive feelings toward the place and community and those who more often participate at local meetings (Slavuj, 2012).

Jelić and Löw Stanić (2014) included the dimension of social interaction with neighbors in the analysis of functional and emotional attachment to the place of living. The analysis demonstrated that frequency of socializing with neighbors represents a significant predictor of place attachment. Although local social relations represent the independent variable in this research, conducted analysis is interesting because through analysis of inter-connectedness of all used criteria and predictor variables, it indirectly indicated something about determinants of local social relations. More precisely, the analysis showed that socializing with neighbors is in positive correlation only with the economic status of respondents.

Although results of selected researches do not offer a unique determinant for the structure of local social relations, they nevertheless reveal that social interaction in neighborhood is related to some characteristics of its actors as well as to context within which these social relations take place. Taking into consideration these facts and the mentioned lack of basic insights into the patterns of forming local social relations in Croatian society, this paper aims to achieve two basic goals. The first is to get insight into the structure of local social relations in Croatia, and the second is to test the hypothesis that the structure of local social relations in Croatia is related to demographic and socioeconomic characteristics and residential status of actors.

\section{Methodology}

\subsection{Data Collection}

A survey entitled Pilar's Barometer of Croatian Society served as a source of data analyzed in this paper. The survey was conducted by the Institute of Social Sciences Ivo Pilar in the period from March 2014 to May 2014. In addition to collecting data about the problem of local social relations, the survey encompassed a broad range of socially relevant topics. The research data were collected by face-to-face interview at the respondent's home address. The target population were citizens of Croatia aged 18 years and over. The research was conducted on a total number of 1000 respondents using a multi-stage stratified probability sampling design. The response rate was $66.5 \%$ and, except for educational status, the achieved sample was a close reflection of the target population. In order to obtain the sample that adequately represents target population the data were weighted on the basis of age, sex, and educational attainment of the Croatian population according to the 2011 census.

\subsection{Instruments}

The Neighborhood Relations Scale used in this research has been developed by Prezza, Amici, Roberti and Tedeschi (2001) and, to a certain extent it is based on the Bruckner's (1988) instrument for measuring social cohesion of neighborhood. The 
Neighborhood Relations Scale contains seven items describing two aspects of local social relations: five of the items address frequency, and two density of local social relations. The frequency of interaction by types of local social relations was measured on a scale from 1 (never) to 5 (every day). The density of local social relations was measured by two open-ended questions ('how many of your neighbors would you have no problem asking to borrow little things' and 'how many of your neighbors do you consider as your friends'). The data collected for these two open-ended questions were subsequently re-coded into a 5-item scale as follows: responses 'all', 'a lot' and those indicating number ' 7 or more' were scored 5; responses 'majority' and number 5 or 6 were scored 4; responses 'enough of them', 'sufficient number' and number 3 or 4 were scored 3; responses 'few', 'several' or number 1 and 2 were scored 2; responses 'none' and number zero were scored 1.

The demographic characteristics included in the analysis were sex and age of the respondents, and the socioeconomic characteristics were those describing the average monthly income per household member and the highest level of education achieved by respondents. Residential status was based on place of residence - size of settlement and building where respondents live - and residential history - such as whether respondent has always lived in a given neighborhood and how many years in total he/she lived at the current residential address. Basic characteristics of the sample regarding mentioned variables are presented in Table 1.

Table 1

Basic characteristics of the sample

\begin{tabular}{|c|c|c|}
\hline Variable & Category & $\%$ \\
\hline \multirow{2}{*}{ Sex } & Males & 51.7 \\
\hline & Females & 48.3 \\
\hline \multirow{3}{*}{ Age } & $18-34$ years & 25.7 \\
\hline & $35-64$ years & 52.2 \\
\hline & +65 years & 22.1 \\
\hline \multirow{3}{*}{$\begin{array}{l}\text { Average monthly income per } \\
\text { household member } \\
\text { (in HRK) }\end{array}$} & $<1,500$ & 33.4 \\
\hline & $1,500-4,000$ & 51.8 \\
\hline & $>4,000$ & 14.8 \\
\hline \multirow{3}{*}{ Level of education } & Elementary school, incl. incomplete & 31.0 \\
\hline & Secondary school & 53.0 \\
\hline & College or university & 16.0 \\
\hline \multirow{3}{*}{ Type of settlement } & $>75,000$ inhabitants & 22.7 \\
\hline & $1,500-75,000$ & 45.2 \\
\hline & $<1,500$ & 32.1 \\
\hline \multirow{2}{*}{ Type of building } & $1-2$ apartments & 72.5 \\
\hline & 3 or more apartments & 27.5 \\
\hline \multirow{2}{*}{$\begin{array}{l}\text { Has he/she always lived in a } \\
\text { given neighborhood? }\end{array}$} & 1. Yes & 43.4 \\
\hline & 2. No, moved later & 56.6 \\
\hline \multirow{3}{*}{$\begin{array}{l}\text { Number of years living at the } \\
\text { current residential address }\end{array}$} & 5 years or less & 17.9 \\
\hline & $6-20$ years & 33.0 \\
\hline & 20 years or more & 49.2 \\
\hline
\end{tabular}




\section{Results}

Table 2 shows central tendency and dispersion measures for responses collected on the scale measuring social relations in the neighborhood. For better clarity, results for questions that refer to frequency were presented separately from those describing density of neighborhood social relations. Distribution of responses on the frequency measuring items reveals that engaging in casual conversation represents the most frequent type of social interaction with neighbors, and almost 60\% of respondents reported that they do this often or every day. Contrary to this, only between one-fourth and one-fifth of respondents reported that they exchange visits with neighbors or exchange favors or spend time doing things with neighbors on a daily basis. Also, respondents somewhat more often received visits from their neighbors rather than they participated in joint activities or exchanged favors with their neighbors.

For both variables measuring density of neighborhood social relations, the most frequent score was 2 . As mentioned previously, the scale range is from 1 to 5 , and the score of 2 included the responses 'few', 'several', and numbers 1 or 2 . These results reveal that about one-third of respondents have few friends among neighbors, and about one-fourth of them have no friends at all. When speaking about the possibility of borrowing little things from the neighbors, about 30\% of respondents declared that they could ask only few neighbors to borrow something, and for about $13 \%$ of respondents that there were no such persons in their neighborhood.

Table 2

Neighborhood Relations Scale

\begin{tabular}{|c|c|c|c|c|c|c|c|c|}
\hline $\begin{array}{l}\text { Subscale 1: Frequency } \\
\text { of interaction with } \\
\text { neighbors }\end{array}$ & ¿̀ & $\frac{\vec{d}}{\frac{d}{2}}$ & 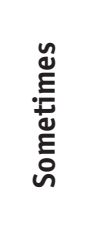 & $\stackrel{5}{\frac{5}{4}}$ & $\begin{array}{l}\overrightarrow{0} \\
\frac{\pi}{0} \\
\frac{1}{4}\end{array}$ & 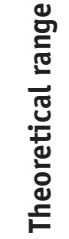 & 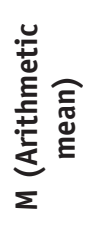 & 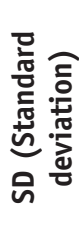 \\
\hline $\begin{array}{l}\text { 1.Visiting neighbors in their } \\
\text { home }\end{array}$ & $12.5 \%$ & $28.5 \%$ & $35.1 \%$ & $20.2 \%$ & $3.7 \%$ & $1-5$ & 2.74 & 1.03 \\
\hline $\begin{array}{l}\text { 2. Being visited by neighbors } \\
\text { in own home }\end{array}$ & $10.7 \%$ & $25.5 \%$ & $36.9 \%$ & $23.0 \%$ & $3.9 \%$ & $1-5$ & 2.84 & 1.02 \\
\hline 3. Stop and talk to neighbors & $3.1 \%$ & $8.6 \%$ & $29.4 \%$ & $42.6 \%$ & $16.3 \%$ & $1-5$ & 3.60 & 0.96 \\
\hline $\begin{array}{l}\text { 4. Spend time doing things } \\
\text { with neighbors }\end{array}$ & $23.6 \%$ & $25.5 \%$ & $31.3 \%$ & $16.9 \%$ & $2.7 \%$ & $1-5$ & 2.49 & 1.11 \\
\hline $\begin{array}{l}\text { 5. Exchanging favors with } \\
\text { neighbors }\end{array}$ & $16.5 \%$ & $24.1 \%$ & $37.8 \%$ & $18.2 \%$ & $3.4 \%$ & $1-5$ & 2.68 & 1.06 \\
\hline \multicolumn{6}{|c|}{ Subscale 1 -Total } & $5-25$ & 14.35 & 4.34 \\
\hline
\end{tabular}




\begin{tabular}{|c|c|c|c|c|c|c|c|c|}
\hline $\begin{array}{l}\text { Subscale 1: Density } \\
\text { of interaction with } \\
\text { neighbors }\end{array}$ & 1 & 2 & 3 & 4 & 5 & 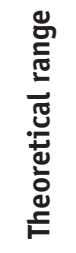 & $\Sigma$ & ำ \\
\hline $\begin{array}{l}\text { 6. How many of your } \\
\text { neighbors would you have } \\
\text { no problem asking to } \\
\text { borrow little things? }\end{array}$ & $12.7 \%$ & $29.9 \%$ & $23.2 \%$ & $18.8 \%$ & $15.3 \%$ & $1-5$ & 2.94 & 1.27 \\
\hline $\begin{array}{l}\text { 7. How many of your } \\
\text { neighbors do you consider } \\
\text { as your friends? }\end{array}$ & $26.2 \%$ & $33.3 \%$ & $17.6 \%$ & $12.0 \%$ & $10.9 \%$ & $1-5$ & 2.48 & 1.29 \\
\hline \multicolumn{6}{|c|}{ Subscale 2 -Total } & $2-10$ & 5.43 & 2.35 \\
\hline \multicolumn{6}{|c|}{ NEIGHBORHOOD RELATIONS SCALE - TOTAL } & $7-35$ & 19.67 & 6.13 \\
\hline
\end{tabular}

From Table 3 it is evident that items used to measure neighborhood social relations show mutual strong or very strong and statistically significant association in positive direction. This mutual relationship among items allowed certain summarizing of the instrument, as was done in the next step of analysis.

Table 3

Pearson's correlation coefficient between items included in the scale of neighborhood relations

\begin{tabular}{|l|c|c|c|c|c|c|}
\hline & $\mathbf{1 .}$ & $\mathbf{2 .}$ & $\mathbf{3 .}$ & $\mathbf{4}$ & $\mathbf{5 .}$ & $\mathbf{6 .}$ \\
\hline 1.Visiting neighbors in their home & - & & & & & \\
\hline 2. Being visited by neighbors in own home & $0.87^{* *}$ & - & & & & \\
\hline 3. Stop and talk to neighbors & $0.53^{* *}$ & $0.54^{* *}$ & - & & & \\
\hline $\begin{array}{l}\text { 4. Spend time doing things with neighbors } \\
\text { 5. Exchanging favors with neighbors }\end{array}$ & $0.62^{* *}$ & $0.65^{* *}$ & $0.47^{* *}$ & - & & \\
\hline $\begin{array}{l}\text { 6. How many of your neighbors would you have no } \\
\text { problem asking to borrow little things? }\end{array}$ & $0.47^{* *}$ & $0.47^{* *}$ & $0.47^{* *}$ & $0.42^{* * *}$ & $0.47^{* * *}$ & - \\
\hline $\begin{array}{l}\text { 7. How many of your neighbors do you consider as } \\
\text { your friends? }\end{array}$ & $0.47^{* * *}$ & $0.47^{* *}$ & $0.41^{* *}$ & $0.43^{* *}$ & $0.43^{* * *}$ & $0.68^{* *}$ \\
\hline
\end{tabular}

${ }^{* *} p<0.01$

Since the content of the instrument for measuring neighborhood social relations included two aspects, summarizing was conducted on two subscales; one measuring frequency and the other measuring density of social relations with neighbors. On 
the subscale measuring frequency, justification of this procedure was additionally verified by factor analysis. Factor analysis on the frequency subscale, using the principal components analysis method, identified one factor with an eigenvalue above 1 (Table 4). This factor accounted for $70.51 \%$ of variance and showed strong internal consistency. More precisely, all the items had factor loadings greater than 0.7 , and Cronbach's alpha score for this factor was 0.894 (Table 5). These results justify reduction of the subscale to a single variable by summing up all five items. Theoretical range for the variable created in this way is from 5 to 25 , and a higher result on the scale indicates greater frequency of social relations in neighborhood.

Table 4

Results of factor analysis using the method of principal components on the subscale for frequency of neighborhood social relations: characteristic roots and proportion of interpreted variance

\begin{tabular}{|c|c|c|}
\hline Factor & Eigenvalues & \% of variance \\
\hline 1 & 3.53 & 70.51 \\
\hline 2 & 0.59 & 11.84 \\
\hline 3 & 0.56 & 11.10 \\
\hline 4 & 0.20 & 3.94 \\
\hline 5 & 0.13 & 2.67 \\
\hline
\end{tabular}

Table 5

Results of factor analysis using the method of principal components on the subscale for frequency of neighborhood social relations: rotated component and Cronbach's alpha

\begin{tabular}{|l|c|c|}
\hline & Rotated component & Cronbach's alpha \\
\hline 1. Visiting neighbors in their home & 0.873 & 0.894 \\
\hline 2. Being visited by neighbors in own home & 0.891 \\
\hline 3. Stop and talk to neighbors & 0.715 \\
\hline 4. Spend time doing things with neighbors & 0.849 \\
\hline 5. Exchanging favors with neighbors & 0.859 & \\
\hline
\end{tabular}

The subscale masuring density of social relations with neighbors consists of two mutually strongly correlated items. They were summarized to one variable with a theoretical range from 2 to 10, where greater number denotes greater density of social relations in neighborhood.

Table 6 shows results achieved by respondents on the two previously described subscales, grouped according to their demographic (sex and age) and socioeconomic characteristics (average monthly income per household member and the highest level of education achieved) as well as according to the respondent's residential status (size of settlement and building where respondents live, whether he/ she always lived in the current neighborhood and how many years in total he/she resided at the current address). Also, the results of the analysis of variance, t-test and post-hoc analysis (Tukey HSD) used to test statistically significant differences of the mean values, are presented. 
Table 6

Differences in the results obtained on the scale of neighborhood relations by sex, age, average monthly income per household member, highest level of education achieved, type of settlement, type of building, length of living in neighborhood and number of years living at the current residential address

\begin{tabular}{|c|c|c|c|c|c|c|c|c|c|}
\hline \multirow{2}{*}{\multicolumn{2}{|c|}{ M }} & \multicolumn{4}{|c|}{$\begin{array}{l}\text { Subscale for frequency of } \\
\text { neighborhood social relations }\end{array}$} & \multicolumn{4}{|c|}{$\begin{array}{l}\text { Subscale for density of } \\
\text { neighborhood social relations }\end{array}$} \\
\hline & & SD & $\begin{array}{l}\text { T-test } \\
\text { or }\end{array}$ & $\begin{array}{l}\text { Post- } \\
\text { hoc }\end{array}$ & $M$ & SD & $\begin{array}{c}\text { T-test } \\
\text { or }\end{array}$ & $\begin{array}{l}\text { Post- } \\
\text { hoc }\end{array}$ & \\
\hline \multirow{2}{*}{$\stackrel{\times}{\sim}$} & Males & 14.60 & 4.53 & \multirow{2}{*}{-1.745} & & 5.54 & 2.47 & \multirow{2}{*}{-1.517} & \\
\hline & Females & 14.12 & 4.14 & & & 5.32 & 2.23 & & \\
\hline \multirow{3}{*}{ 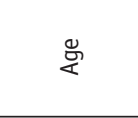 } & $18-34$ & 13.56 & 4.59 & \multirow{3}{*}{$5.819^{* * *}$} & \multirow{3}{*}{$\begin{array}{l}1-2^{* *} \\
1-3^{*}\end{array}$} & 5.06 & 2.22 & \multirow{3}{*}{$4.364^{*}$} & \multirow{3}{*}{$\begin{array}{l}1-2^{*} \\
1-3^{*}\end{array}$} \\
\hline & $35-64$ & 14.67 & 4.30 & & & 5.51 & 2.34 & & \\
\hline & $65+$ & 14.51 & 4.04 & & & 5.65 & 2.47 & & \\
\hline \multirow{3}{*}{ 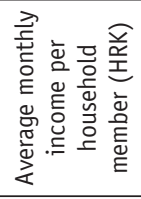 } & $<1,500$ & 14.80 & 4.51 & \multirow{3}{*}{2.410} & & 5.88 & 2.48 & \multirow{3}{*}{$7.917^{* *}$} & \multirow{3}{*}{$\begin{array}{l}1-2^{* * *} \\
1-3^{*}\end{array}$} \\
\hline & $\begin{array}{c}1.500- \\
4,000\end{array}$ & 14.25 & 4.15 & & & 5.28 & 2.22 & & \\
\hline & $>4,000$ & 13.96 & 4.46 & & & 5.19 & 2.25 & & \\
\hline \multirow{3}{*}{ 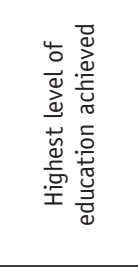 } & $\begin{array}{c}\text { Elementary } \\
\text { school, incl. } \\
\text { incomplete }\end{array}$ & 15.04 & 4.59 & \multirow{3}{*}{$11.971^{\text {*** }}$} & \multirow{3}{*}{$\begin{array}{l}1-3^{* *} \\
2-3^{* *}\end{array}$} & 5.89 & 2.52 & \multirow{3}{*}{$13.132^{* * *}$} & \multirow{3}{*}{$\begin{array}{l}1-2^{* * *} \\
1-3^{* * *} \\
2-3^{*}\end{array}$} \\
\hline & $\begin{array}{l}\text { Secondary } \\
\text { school }\end{array}$ & 14.36 & 4.17 & & & 5.36 & 2.38 & & \\
\hline & $\begin{array}{l}\text { College or } \\
\text { university }\end{array}$ & 12.98 & 4.09 & & & 4.75 & 1.84 & & \\
\hline \multirow{3}{*}{ 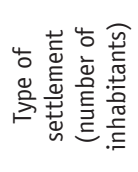 } & $>75,000$ & 13.18 & 4.34 & \multirow{3}{*}{$15.674^{* * *}$} & \multirow{3}{*}{$\begin{array}{l}1-2^{* * *} \\
1-3^{* *} \\
2-3^{*}\end{array}$} & 4.87 & 2.15 & \multirow{3}{*}{$9.258^{* * *}$} & \multirow{3}{*}{$\begin{array}{l}1-2^{* * *} \\
1-3^{* * *}\end{array}$} \\
\hline & $\begin{array}{l}1,500- \\
75,000\end{array}$ & 14.30 & 4.28 & & & 5.49 & 2.30 & & \\
\hline & $<1,500$ & 15.26 & 4.24 & & & 5.72 & 2.48 & & \\
\hline \multirow{2}{*}{ 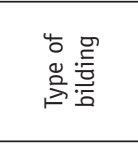 } & $\begin{array}{c}1-2 \\
\text { apartments }\end{array}$ & 14.85 & 4.26 & \multirow{2}{*}{$6.496^{* * *}$} & & 5.66 & 2.40 & \multirow{2}{*}{$5.207^{* *}$} & \\
\hline & $\begin{array}{c}3 \text { or more } \\
\text { apartments }\end{array}$ & 12.84 & 4.29 & & & 4.82 & 2.15 & & \\
\hline \multirow{2}{*}{ 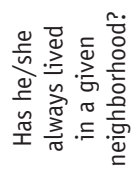 } & 1. Yes & 14.91 & 4.39 & \multirow{2}{*}{$3.579^{* * *}$} & & 5.77 & 2.45 & \multirow{2}{*}{$4.063^{* *}$} & \\
\hline & $\begin{array}{l}\text { 2. No, } \\
\text { moved later }\end{array}$ & 13.92 & 4.25 & & & 5.16 & 2.23 & & \\
\hline \multirow{3}{*}{ 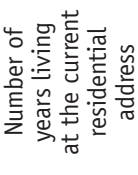 } & 5 or less & 13.40 & 4.77 & \multirow{3}{*}{$13.462^{* * *}$} & & 4.60 & 2.14 & & \\
\hline & $6-20$ & 13.81 & 4.28 & & $\begin{array}{l}1-3^{* * *} \\
2-3^{\text {*** }}\end{array}$ & 5.14 & 2.26 & $25.460^{\text {**** }}$ & $1-3^{* * *}$ \\
\hline & 21 or more & 15.05 & 4.11 & & & 5.92 & 2.37 & & \\
\hline TO & & 14.35 & 4.34 & & & 5.43 & 2.35 & & \\
\hline
\end{tabular}

* $p<0.05$

** $p<0.01$ 
First, we shall discuss the differences in the frequency of social relations in neighborhood. As distribution shows, in the two analyzed demographic characteristics (age and sex) a statistically significant difference was determined only for age. Post-hoc test indicated that the respondents aged from 18 to 34 years have significantly more frequent social relations with neighbors in comparison to the other two age groups. In the context of socioeconomic characteristics, the analysis showed statistically significant difference only by level of respondents' education. As the distribution for the frequency of social relations with neighbors shows, the overall scale value decreases with the increase in educational level, and the post-hoc test showed statistically significant differences between the respondents who completed elementary school and those with a college or university diploma, and between the respondents who completed secondary school and those with a college or university diploma.

In relation to residential status, the differences found for the frequency of social relations with neighbors were statistically significant on all four analyzed variables. More precisely, the analysis showed that the frequency of interactions with neighbors decreases with the increase in settlement size, and that survey respondents living in a building with 3 or more apartments socialize with neighbors more rarely than those living in a building with 1 or 2 apartments.

The frequency of social relations within the neighborhood was also associated with the migration experience of survey respondents; according to our results, those who have always lived in the same place maintain more frequent contacts with their neighbors. The difference on the last analyzed variable relating to the length of time one has resided at the current address indicates an association between the increase in the number of years and more frequent social relations with neighbors. According to the post-hoc test, there are statistically significant differences between the group of respondents living 5 years or less and the group living more than 20 years at the current residential address, as well as between the group of respondents who lived between 6 and 20 years and those living more than 20 years at the current residential address.

On the subscale measuring density of social relations in neighborhood, statistically significant differences were identified between the groups formed according to their demographic and socioeconomic characteristics and their residential status on almost all analyzed independent variables. Specifically, sex is the only independent variable where no statistically significant difference was determined on this subscale. A more detailed analysis indicated that patterns of occurrences for the differences in the density of social relations correspond considerably to the patterns seen on the scale measuring frequency of neighborhood social relations. Among the three categories based on age, the youngest respondents (18-34 years of age) showed the lowest density of neighborhood social relations. Additionally, analysis of differences with regard to average income showed the densest network of interactions within neighborhood among respondents with the lowest monthly income. Regarding the other analyzed socioeconomic variable, the one that relates to the respondents' educational attainment, the analysis of statistical significance showed that the density of social relations decreases with the increase in the level of respondents' education. 
Statistically significant variables that describe residential status of survey respondents indicate that those from the largest Croatian urban areas (settlements with population over 75,000) have lower density of neighborhood social relations in comparison to respondents from the other two categories of smaller settlements. The differences were also identified with regard to the size of buildings; a greater density of neighborhood social relations was determined for the respondents living in the buildings with 1 or 2 apartments. As for the relationship between migration experience and years of living at the current residential address and the density of neighborhood social relations, the analysis showed greater density for the respondents who are living in a given neighborhood all the time than for those who have moved there later. In the three groups formed according to the duration of living at the current residential address, the greatest density of neighborhood social relations was found in the respondents living in the neighborhood for 21 years or longer, and the least in those who lived at the current residential address 5 years or less.

\section{Discussion}

The analysis presented in this paper is focused on the structure of local social relations in Croatian society. Specifically, the paper aims to examine the structure of social relations at the neighborhood level and to find out who is more and who is less inclined to build social relations with neighbors. In this research the neighborhood was defined based on human scale as the area contained within the radius of up to a 15-minute walking distance from one's home. The analysis of the data collected in the survey gave several insights.

First, regarding the frequency of different forms of social interaction with neighbors, the analysis showed that casual, naturally-occurring conversations with neighbors represent the most frequent form of social interaction. This kind of social interaction may simply reflect politeness rather than deep and strong social relations with neighbors. The deeper and stronger social ties were explored through the remaining four frequency-measuring subscale items. According to the results, respondents are slightly less inclined to engage in forms of social interactions with their neighbors that are characteristic for stronger ties. Even for the frequency of receiving visits from neighbors, which is the second most prevailing form of spending time with them, as little as $25 \%$ of respondents reported that this occurs often or every day. Certainly, being visited by neighbors or visiting them in their homes is not necessarily an indication of strong social ties; however, engaging in this type of social interaction usually implies certain level of closeness. Anyway, the respectable number of $65 \%$ of respondents who reported having more intensive social relation with neighbors was reached only after lowering the threshold and when including those who reported having social interaction with neighbors sometimes. Now, the question is whether by lowering criteria we still remain within the framework of what could be considered deep and strong local social relations.

When analysing the number of neighbors included in respondent's local social network, our results suggest that there are relatively dense social interactions among 
neighbors. About 57\% of all respondents reported a considerable number of neighbors ('more of them', 'majority' or 'all') they could ask to borrow some little things, while $40 \%$ of respondents reported having a considerable number of neighbors with whom they developed friendship. Comparison of results obtained for the two items measuring density of local social relations reveals that the group of neighbors who could be asked to borrow some little things is somewhat greater than the group of neighbors who are considered friends. This is not surprising, because exchanging things with neighbors functions as a social norm and, as such, it can be a starting point for development of more complex social relations - and some of them may eventually end in friendship.

The analysis of differences in frequency and density of social relations by respondents' demographic and socioeconomic characteristics, as well as by their residential status, points to certain stable differences between the groups. Respondents' educational attainment (higher attained level of education implies more rarely socializing with neighbors) and size of settlement and building where respodents live (those living in larger settlements and bigger buildings socialize with their neighbors more rarely) were identified as the most significant determinants of neighborhood social relations. Also, our results showed that length of living at the current residential address is of particular importance for the density of social interactions within neighborhood; longer living at the current address results in denser local social relations.

Findings from this analysis partially correspond to the results from previously reviewed studies. In this research, the mean value obtained on the neighborhood social relations scale (19.67) only slightly exceeds the value obtained by the identical instrument (19.07) in the already mentioned Italian study (Prezza et al., 2001). However, this comparison does not reveal much. The only conclusion that could be drawn is that local social relations in Croatia do not basically differ from those in Italy.

Furthermore, the Italian study (Prezza et al., 2001) revealed that lower level of education and the length of living at the current address are related to more intensive social relations within neighborhood which is consistent with the results of our analysis. However, in Croatia, opposite to the findings from the Italian study, the respondents' sex was not of much relevance to the structure of local social relations. Additionally, similar to our finding, the length of living at the current residential address was also identified as strongly related to local social relations in the previously mentioned Slovenian study (Filipovič Hrast and Dolničar, 2012). This study also determined that the height of income partially influences local social relations, which corresponds with our finding that higher income groups socialize with fewer neighbors compared to lower income groups.

Finally, returning to the question asked in the title of this paper and to the main objectives of the research, the analysis suggests that in Croatian society socializing with neighbors is still retained as a common form of social interaction for a sizable segment of the population. To summarize, about half of respondents maintain social relations with somewhat greater number of neighbors, about $60 \%$ of them stop 
and talk to neighbors while only one fourth of them exchange visits with neighbors more frequently. The results of analysis also confirmed that respondents' residential status was more associated with local social relations compared to respondents's demographic and socioeconomic characteristics - social relations with neighbors are very often a result of long-term process while the physical density of social actors, typical for larger settlements, does not offer fertile grounds for development of more intensive local social relations.

More thourough understanding of the problems of the local social relations in Croatian society requires additional empirical insights, and particularly about the role of a neighborhood as a context that provides or does not provide opportunities for social activities and social interaction. Aiming to explore this aspect, future researches of local social relations should pay more attention to the characteristics of neighborhood, mostly relating to its social composition. One of possible research approaches that could be taken to measure the influence of neighborhood character is investigating local social relations in a small number of mutually different neighborhoods. Additionally, some future research should try to differentiate closer from less close local ties. These types of insights will be important for better understanding of the dynamics of social interaction within a group of people living near one another.

\section{References}

1. Bruhn, J. G. (2011). The Sociology of Community Connections. New York: Springer.

2. Buckner, J. C. (1988). The Development of an Instrument to Measure Neighbourhood Cohesion. American Journal of Community Psychology, 16 (6): 771-791.

3. Castells, M. (2000). Uspon umreženog društva. Zagreb: Golden marketing.

4. Chombart de Lauwe, P. H. (1961). The Sociology of Housing Methods and Prospects of Research. International Journal of Comparative Sociology, 2 (1): 23-41.

5. Colantonio, A. \& Dixon, T. (2010). Urban Regeneration and Social Sustainability: Best Practice from European Cities. Wiley-Blackwell.

6. Dempsey, N.; Bramley, G.; Power, S.; Brown, C. (2011). The Social Dimension of Sustainable Development: Defining Urban Social Sustainability. Sustainable Development, 19 (5), 289-300.

7. Filipovič Hrast, M. and Dolničar, V. (2012). Sense of Community and the Importance of Values: Comparison of Two Neighborhoods in Slovenia. Journal of Urban Affairs, 34 (3): 317-336.

8. Forrest, R. and Kearns, A. (2001). Social Cohesion, Social Capital and the Neighbourhood. Urban Studies, 38 (12): 2125-2143.

9. Galster, G. (2001). On the Nature of Neighbourhood. Urban Studies, 38 (12): 2111-2124.

10. Guest, A. M. and Wierzbicki, S. K. (1999). Social Ties at the Neighborhood Level: Two Decades of GSS Evidence. Urban Affairs Review, 35 (1): 92-111.

11. Halfacree, K. (2012). Heterolocal Identities? Counter-Urbanisation, Second Homes, and Rural Consumption in the Era of Mobilities. Population, Space and Place, 18 (2), 209-224. 
12. Hipp, J. R.; Faris, R. W. and Boessen, A. (2012). Measuring "Neighborhood": Constructing Network Neighborhoods. Social Networks, 34 (1): 128-140.

13. Hunter, A. (1979). The Urban NeighBorhood its Analytical and Social Contexts. Urban Affairs Review, 14 (3): 267-288.

14. Jacobs, J. (1961). The Death and Life of Great American Cities. New York: Random House.

15. Jelić, M. and Löw Stanić, A. (2014). Utjecaj socio-ekonomske strukture susjedstva na privrženost susjedstvu. Socijalna ekologija, 23 (2): 151-174.

16. Kearns, A. and Parkinson, M. (2001). The Significance of Neighbourhood. Urban Studies, 38 (12): 2103-2110.

17. Kemeny, J. (1992). Housing and Social Theory. Routledge.

18. King, K. (2013). Jane Jacobs and "The Need for Aged Buildings": Neighborhood Historical Development Pace and Community Social Relations. Urban Studies, 50 (12): 2407-2424.

19. Kramer, S.; Seedat, M.; Lazarus, S.; Suffla, S. (2011). A Critical Review of Instruments Assessing Characteristics of Community. South African Journal of Psychology, 41 (4): 503-516.

20. Kubrin, C. E. and Weitzer, R. (2003). New Directions in Social Disorganization Theory. Journal of Research in Crime and Delinquency, 40 (4): 374-402.

21. Martin, D. (2003). Enacting Neighborhood. Urban Geography, 24(5): 361-385.

22. Norberg-Schulz, C. (1990). Stanovanje: stanište, urbani prostor, kuća. Beograd: Građevinska knjiga.

23. Prezza, M.; Amici, M.; Roberti, T.; Tedeschi, G. (2001). Sense of Community Referred to the Whole Town: Its Relations with Neighboring, Loneliness, Life Satisfaction, and Area of Residence. Journal of Community Psychology, 29 (1): 29-52.

24. Seferagić, D. (1988). Kvaliteta života i nova stambena naselja. Zagreb: Sociološko društvo Hrvatske.

25. Slavuj, L. (2012). Evaluacija kvalitete urbanoga susjedstva - prednosti i nedostaci neposrednoga životnog prostora. Sociologija i prostor, 50 (2): 183-201.

26. Smith, R. A. (1975). Measuring Neighborhood Cohesion: A Review and Some Suggestions. Human Ecology, 3 (3): 143-160.

27. Suttles, G. D. (1972). The Social Construction of Communities. Chicago: University of Chicago.

28. Svirčić Gotovac, A. (2006). Kvaliteta stanovanja u mreži naselja Hrvatske. Sociologija sela, 171 (1): 105-126.

29. Wellman, B. and Leighton, B. (1979). Networks, Neighborhoods, and Communities: Approaches to the Study of the Community Question. Urban Affairs Review, 14 (3): 363-390. 
Geran-Marko Miletić

Institut društvenih znanosti Ivo Pilar, Zagreb, Hrvatska

e-mail: Geran-Marko.Miletic@pilar.hr

Tko se (još) druži sa susjedima? Prilog analizi lokalnih društvenih odnosa

\section{Sažetak}

Izvlačenje društvenih odnosa iz lokalnog konteksta često se spominje kao jedno od bitnih obilježja suvremenih društvenih promjena. Upravo polazeći od toga ovim radom se propitivala uloga koju danas društveni odnosi u susjedstvu imaju u hrvatskom društvu. Dva su osnovna cilja ovoga rada: prvi cilj je dobiti uvid u obilježja strukture lokalnih društvenih odnosa u Hrvatskoj, a drugi cilj je utvrditi je li dinamika lokalnih društvenih odnosa povezana s nekim osnovnim sociodemografskim, socioekonomskim te prostornim čimbenicima. U analizi su korišteni podaci prikupljeni anketnim istraživanjem Pilarov barometar hrvatskog društva. Istraživanje je provedeno u proljeće 2014. godine na reprezentativnom uzorku građana Hrvatske starijih od 18 godina $(\mathrm{N}=1000)$. Dobiveni nalazi upućuju na to da je u hrvatskom društvu druženje sa susjedima još uvijek uobičajeni oblik socijalne interakcije za većinu stanovništva. Kao najznačajnije odrednice društvenih odnosa među susjedima pokazale su se stupanj obrazovanja te veličina naselja i zgrade u kojoj ispitanici žive. Osim toga, posebno važnim za gustoću društvenih odnosa u susjedstvu se pokazao broj godina provedeno na sadašnjoj adresi stanovanja.

Ključne riječi: lokalni društveni odnosi, lokalna zajednica, susjedstvo, socijalna kohezija, Pilarov barometar, Hrvatska. 